\title{
Facing the Ugly Face
}

Erika Goble, PhD(c), Department of Secondary Education, University of Alberta, Edmonton, AB, Canada

E-mail: egoble@ualberta.ca

\section{Abstract}

Ugliness is largely considered an aesthetic, cultural construct and, though infrequently defined, is often seen as the opposite of existing conceptions of beauty. This definition of ugliness, however, provides little understanding of the lived experience of encountering it, particularly when that ugliness is found upon the face of another. This article explores the questions: what is ugliness? And what does it mean to experience another person as ugly? Through describing the experience of encountering an ugly face, ugliness is explored as a highly embodied, interpersonal experience that implicates the person who sees and recognizes another's ugliness as much as it involves the ugly person, him- or herself.

\section{Facing the Ugly Face}

I can recall the day clearly. It is the first day of gym class and everyone is nervously looking around, trying not to get caught checking each other out. A movement catches my eye and I notice a girl enter the room. Ugggg - her visage immediately strikes me. It is as if all of her features have been crammed onto the smallest surface area possible on the front of her head - except for her eyes, which have been left far apart to the sides. As I study her oddly arranged features, all I can think is "poor thing, to have such a face." Suddenly, I catch myself. I hope no one has noticed that I have been staring. I quickly look down at my shoes. Watching my feet shift nervously on the gym floor, I wonder if she feels bad for looking that way. I feel bad for her.

What is ugliness? What does it mean to say that you find something, someone, ugly? What is it to experience someone as ugly? We often use the word 'ugly' without considering it. We may assume we know what ugliness is because we can point to something and say, "That is ugly." Children are told not say ugly words. Sofas, once fashionable, now out-of-date, faded, stained and relegated to the basement den, are readily called ugly. That Christmas sweater, adorned with bells and bows but knitted by an aunt so it cannot be refused or discarded, is recognizably ugly. Even my bulldog, a creature dear to my heart, is ugly in her gargoylishness - though I qualify it with affection: she is so ugly she is cute. Once we begin to look, we notice that ugly things surround us (even if we might hesitate to say it aloud). Ugliness seems a given, recognizable 
feature of things, even if it is a somewhat individual and culturally specific designation (Pereiro, 2006).

So what is ugliness? Many scholars suggest that ugliness is the opposite of a culturally prescribed notion of beauty (Burke, 1958/2008; Eco, 2007; Gigante, 2000; Gillman, 1995; Lorrand, 1994): if thin is beautiful, fat is ugly; if large, wide-set eyes are beautiful, then narrow, close-set eyes are ugly. But ugliness cannot be so simple. The thin willow is no more beautiful than the solid oak. This dichotomy is not limited to nature. Many would hesitate to declare the skeletal frame of an anorexic patient to be beautiful, and just as few would decry the voluptuous women of Ruben's paintings as ugly. Likewise, large wide-set eyes are not always beautiful. Set too wide or simply being too large and we no longer see something attractive; the face may be perceived as distorted, alien, even ugly (Green, MacDorman, Ho, \& Vasudevan, 2008).

Ugliness, then, is something more complex than a simple set of cultural rules. Contemporary science suggests that human beings find beauty in symmetry and the harmony of form, and ugliness in the lack thereof (Green et al., 2008; Quinn \& Slater, 2003). From this perspective, an 'ugly face' is merely a matter of uneven bilateral facial symmetry (Fink, Neave, Manning, \& Grammer, 2006). Other scientists offer a different, though equally simplistic explanation: whereas attractiveness is a positive response to health (Jones et al., 2001; Singh \& Singh, 2011), something appears 'ugly' because it is repugnant, unpleasant, and unhealthy. ${ }^{1}$ Ugliness is understood as a psychological reflex - like gagging - to reject that which is contrary to our wellbeing (Rozin, Haidt, \& Fincher, 2009). ${ }^{2}$ The marks of disease, thus, naturally appear ugly to us. ${ }^{3}$ However, while these various theories are interesting to consider when we wonder why we find something or someone ugly, they provide very little understanding of what it is like to experience ugliness, much less to encounter someone who is ugly. To say that I found the girl in my class ugly because her face did not conform to perfect bilateral symmetry or that my response was a biological aversion to some underlying condition manifesting distorted facial features, offers little understanding of what exactly I experienced. What happened in that moment when I saw her enter the room? In that moment when I first saw her face? To understand that is not however so simple. To understand it, I must return to the experience of encountering the ugly face itself.

\section{Ugliness Speaks: It Demands to be Seen and Demands that I See It}

What happens when, while walking down the street, I suddenly see an ugly face? Quite simply, I take notice. Until that moment, had I been looking at the faces that passed me? While my eyes undoubtedly passed over them, I am not sure that I really saw them for I have difficulty recalling the gender much less any specific features of those whom I have passed. My glance moves on. But when I encounter an ugly face, I notice it. It calls my attention. I can't help but take notice of the ugly girl who enters my class. Her face catches me before I can catch myself rudely staring.

The immediacy and impact of encountering an ugly face reveals that perhaps rather than being an abstract aesthetic category (as many believe), ugliness comes from our world. It seems to be a feature of our world. And when it appears, it demands my notice. An ugly face can bring forth a particular individual from the backdrop of our view and, in so doing, it may also bring us back to ourselves. Here, I am compelled to think back to a recent event: 
I sit on the train gazing out the window, trying to ignore the other passengers. My mind flits from thought to thought as my eyes slide from one reflected face to the next, neither ever really resting long enough to consider.

Then, for some reason, my eyes pause on a distorted face. Slowly, I become aware of its oddity: the too-large head; the forehead that protrudes squished and hanging over the small nose and eyes; the skin color is odd, darkly mottled. Suspecting it to be slight of the glass, I sneak a glance at the actual person. Turning my head and letting my eyes slide over everyone to avoid notice but paying attention only when I reach that one face, I find that the window hasn't lied. The man across the aisle is as distorted as before, perhaps even more so. I turn back to my window, my mind now fully occupied with studying him. I notice how his features are somehow made worse by his coarse black hair cropped short against his skull and the shadow of whiskers left by a poor shave. He leans over his large drink as if to avoid prying eyes. While I do not stop myself from staring at his reflection, I realize that I wouldn't look on him directly - that would be unconscionable. And as I look, emotion wells up in me. I wonder at his life. It is as if I can feel, through the very features of his face and his demeanor, the shame, disrespect, and dismissal that he has experienced. Slowly, my thoughts slip into this imagined life made real by his face. My eyes remain on his reflection until the next stop when he gets up and leaves the train.

The human face serves as a point of contact with others. Indeed, we are not able to stop our gaze from reaching out to those around us. "The appeal of the face is pressing and immediate" (Lingis, 1996, p. 71). Even when we wish to ignore another's presence as is commonly practiced on public transportation, we may still reach out to them through the movement of our eyes. To see you, in particular your face, is to recognize you, even if I may not want to.

Much of this type of "recognition," however, can be largely passive or inattentive. As my eyes move from face to face in the train's window, I recognize the presence of the other passengers but am not called upon to attend to them. It is only when my eyes fall upon a striking face that the face demands to be seen. A strikingly beautiful face may beg my eyes to rest upon it lovingly or, if I pass a beautiful person, his or her face may call for me to follow. An ugly face appears to likewise draw me to it, but rarely with the same reverence and selfless preoccupation. My eyes do not rest easily on the face of my ugly companion on the train. Rather, I know I should not be looking at all. Indeed, I hide my looking by gazing through the window-mirror as I am wary that he might see me. My gaze is furtive, hidden, unlike the easy, open, appreciative gaze I readily give to beauty.

Moreover, when my sight falls on the ugly face $I$ begin to take notice in a way I may not with the beautiful face. Robert Adams (1977) notes how ugliness "is an act of self-consciousness quite distinct from the act of self-forgetfulness that constitutes the classic response to beauty" (p. 100). Whereas the beautiful face makes itself present to me, when the ugly face brings itself to my attention, it calls me into awareness. I become acutely aware that I am seeing it. It is only when I notice the man's oddity that I see him in a way that I do not see the other passengers. Those around him are unremarkable. In their plainness, those faces are not worthy of remark or notice; they do not seem to have a special meaning. Rather like the self-forgetfulness of beauty, 
those other faces and I exist only superficially - barely at all - in the hazy daydream of my morning commute.

The face of the ugly man differs though. It bears meaning. His face literally carries it for me. In the Middle Ages, those born deformed were seen as embodying lessons from God. According to Thomas Bedford (1635), all "monstrous and misshapen births, though dead, yet speake for the Instruction of the living" (in Baker, 2010, p. 34). Though few of us now ascribe to these beliefs, the ugly face may continue to speak and continue to instruct those of us who find that we must look. Indeed, we may find ourselves unable to not look upon and attend to that which issues from the ugly face. For the face of the man on the train, his " “difference' has been marked... [In his ugliness, his] difference signifies. It 'speaks”” (Hall, 1997/2003, p.230). Moreover, its speaking addresses me. His ugliness calls me out of my reverie for "the other's facing comes as a disturbance of order” (Lingis, 1996, p. 71). The ugly face demands to be seen and it demands that $I$ see it, rather than merely that my eyes see it. And by doing so, "it orders me to reorient all the things that exist for me so as to make them common...” (p.71). My hazy world becomes clearly shared.

\section{Ugliness Demands I Share in It, a Sharing which I Refuse}

The significance of the ugly face, however, does more than merely call forth my awareness or even call forth an awareness of myself as being in relation to another. Once aware of the ugliness reflected in the window, it does not suffice that I - now a very conscious I - continue to gaze upon its pale reflection. To see my travelling companion's ugliness in this way seems inadequate for I suspect it might be a distortion of the glass rather than something real. Denise Gigante (2000) notes that, “the ugly stops us in our tracks as something we can’t even imagine” (p. 578). My train companion's apparent ugliness demands that I look directly upon his physical face, if only briefly, as if to assure myself of the actual presence of its ugliness.

Is it merely that I must physically look upon another's ugliness though? Or is there more? Perhaps the answer lies in what I see when I turn to and gaze upon the physically embodied ugliness of another human face. In my train companion, I see a body bowed and worn down under the gazes of others, and mine becomes one more. In that moment I am forced by my own actions to question what I bring to this encounter. In the gesture of my turning towards, do I not also bring a recognition of his presence as ugliness? Do I not become aware that he is aware that I am aware that he is ugly? Phrased in this way, this back and forth can be dizzying. Said differently, my turning towards may invoke an uncomfortable shared awareness of one another, or, a mutual acknowledgement that we have been brought together by an ugliness of which we are both aware but of which neither of us dares speak.

Then, in turning back to the window, do I not turn away from this shared moment so that I may shed or renounce my portion of this burden? I turn away ashamed at my own response and ashamed at my actions. Shame originates in the Proto-Indo-European word kem, meaning "to cover" (Online Etymological Dictionary, 2010). My turning back to the window not retreats from my actions in the hopes of negating that which exists unsaid between us: my acknowledgment of my perception of the other's ugliness. In turning away, do I not hide from the appeal or the request that his face makes of me and of my answering to it: "yes, you are 
ugly”?

\section{Ugliness Demands I Know its Story}

Might there be even more to understand from my act of turning away? Having turned back to my window, I become cognizant that I do so because to continue to look at him would add further weight to my perception of his ugliness and this is unconscionable. It is pure meanness. Like the mythical Medusa, I cannot bear to gaze directly upon him without bringing destruction. And yet, I cannot help but continue to stare at him in the window as Perseus did with his shield. As I gaze at this man's reflection through a vehicle which shields and protects us both from the full presence of ugliness, I begin to sense through the very features of his face - not the least of which, his eyes - the pain of his existence. If the "human countenance is above all an evocation, a reminder of suffering and death. [And] the human face carries within it the trace and the reflection of humanity, as well as the inexorable reminder of weakness and misfortune" (de Saint Cheron, 2010, p. 47), then the ugly face appears only more so. As I look upon the ugly man through the train window, I come to see a lonely creature, cursed by the gods, wandering alone in his cave and unable to be seen by man or beast because of his ugly face. As I think of his face, I wonder if Perseus paused. For in contemplating that ugly face, in stalking it through the train window, I begin to see the ugly man as a human being and as a person before me.

What allows me to see this man in this way? It is, undoubtedly, tied to my perception of his ugliness. While I can readily identify those components which support this perception - his hair cut, the shape of his face, the texture of his skin - the bits do not make up the whole. His appearance remains a mystery to me, as does the face, itself, even my eyes search for its answer. My eyes trace over and over his features until finally he gets up and leaves the train. Even then, my eyes follow him until he is no longer in sight.

In this restless search, what am I looking for? What do I seek? Of what have I caught a glimpse of before his exit? What question does the ugly face beg of me to answer? Is it simply, what makes this person ugly? No. I can enumerate those components. What else might it be then? Rewriting of the myth of Psyche, C.S. Lewis (1956) tells of how her half-sister, Orual, a woman ugly from birth, took to wearing a veil after becoming queen. Her devotion to the veil led to wild conjecture as to its cause and her appearance. What insights might an account of a hidden face offer to understanding the allegedly ugly face exposed? Might it be that through adopting the veil, Orual's face becomes more distinct? Her veil seems to reveal much more than it hides. For those who encounter her, it draws attention to the face as a question, precisely because no answer is forthcoming. In short, it seems to ask those who cannot look upon it to find what lies behind it. Indeed, the veil and ugliness seem to ask me to find what it does not show or to find its story. We do so in the hopes that, like the duckling of Hans Christian Anderson's tale or Orual in C.S. Lewis' own tale, the face, once placed in its proper context, will transform into a thing of beauty.

Might it be then that as I contemplate an ugly face, a face which holds me so strongly that my eyes do not release it until it is out of my sight, that I am searching for the man's story? Am I not trying to find meaning in his face? As I gaze at the man on the train, I become lost in the life I 
imagine for him. Based solely on his features and demeanor, I provide him with a rich narrative that, the longer I look, the more it fills out. As I gaze upon another's exterior in this way, I ask, what life is part of such an appearance? I find myself readily answering: it must be one of pain, shame, and humiliation. I feel as if I have seen inside his life in so far as it may have been marked in some way by his appearance. According to Martha Nussbaum (2010), we only ever come to see another as a human being by imagining the world from that person's perspective: "Only by imagining how the world looks through their eyes does one get to the point of seeing the other person as a someone and not a something” (p. xvii). In being captured by the ugliness of a face, I am called upon to look through that face's eyes. Encountering this person for me forth a kind of pathos. One may enter into another's ugliness, to imagine it as our own, and to wonder: how terrible is it to be ugly?

\section{Ugliness as Abjection \& Repulsion}

To encounter an ugly face can then causes me to see the other in a unique way. Such an encounter may occur even when they are not physically present to us. Consider the following account:

A hideous face appears on the computer screen, ripping at my eyes. Ugghh! Recoiling, I am horrified. Though I can barely look, I force my eyes back to my computer screen, searching for the browser button that will take this away. Bulbous, purple, full of excess blood and veins. Deformed by the ravages of age and neglect. Barely recognizably human. $\underline{\text { Horrible. }}$

The image finally disappears. Even though it is no longer before my eyes, I cannot help but think about the person in that photograph. How terrible it must be for him to look like that. And how appalling it is that someone would photograph him and put the image on the Web as if he was some type of oddity or freak. I am saddened thinking of the medical treatment he should receive but likely won't due to some mundane circumstance like cost or geographical location. But mostly, I feel shame: shame at my own response. For I know that I can only think these things when his image isn't before me. When it is, all I see is ugliness.

This experience appears unique because the ugly face is not physically present to me. Moreover, it is extreme. And yet, my experience remains that of encountering the ugliness of another's face. And in its very extremity, it may be revelatory. When I query my experience, I notice that I respond immediately or prereflectively. I feel attacked by the ugliness of the person who appears before me. In its very appearance, it rips at my eyes, it confronts me and looking away is my only refuge.

With what am I confronted? Certainly it is with the extremity of the disfigurement of the man in the photography. Why, when I look directly upon his ugliness, do I feel horror rather than compassion? The word "ugly" derives from the Old Norse term uggligr, which means "to be feared or dreaded” (Oxford English Dictionary, 2010). Do I fear and dread this man? Rationally, I may say "no - it only a photograph" but irrationally some part of me wants to answer "yes." 
His appearance is dreadful. And it seems to evoke in me a deep fear but of what? As well as the evocation of fear, "dread" also means to evoke "apprehension or anxiety as to future events" (Oxford English Dictionary, 2010). Might my anxiety at this man's ugliness, therefore, be that I am afraid that I might one day look like him? Is it that I fear some possible future for myself that I see in his present ugliness?

Is the above answer too easy? Perhaps there is something more that I fear from this man's ugly face. According to Naomi Baker (2010) and Mark Hutchinson (2002), a face can never be ugly. It is only a face that is not a face, the feature-less face, that is truly ugly. ${ }^{4}$ Thus, is my response to the face of the man on the screen a response to a face that isn't? Is this not the most terrifying prospect: to encounter that which is but at the same time isn't human? If this is the case, might my response to this man's ugliness be the response that we commonly have to what is of us but not of us: that of abjection? My response appears to be quite similar to what is associated with the word abjection: I am horrified, repulsed, and, until the image disappears, unable to make sense of what is happening. I seem to be in the "place where meaning collapses" (Kristeva, 1941, p.2). And like Kristeva's conception of the abject, I banish the image from my sight, first by looking away and then by physically removing it from my screen. Even "from its place of banishment, the abject does not cease challenging its master" (p. 2). I am haunted by the features of the man long after the image disappears: not just immediately following, but for years. Indeed, this experience is the first that comes to mind when I think of an ugly face.

And yet, abjection seems too theoretical, too abstract, too distant a term to describe my experience of the ugly face. "Abjection' is commonly understood as "the state or condition of being cast down or brought low; humiliation, degradation; dispiritedness, despondency,” as well as "the act of casting away, degrading" (Oxford English Dictionary, 2010). While we may imagine the men described above being downcast, despondent, and degraded, even living a wretched life, does my experience of their ugliness necessarily implicate me in that move? Does my perception of their ugliness imply my casting away of the ugly face? Perhaps in extreme cases, as with the photograph. But at other times, the ugly face captures me, causing me to take it up for further consideration. In appearing as ugly, the face is lifted out of the everyday existence of the faceless masses. Indeed, in such a move, it appears anything but abject.

Then how might we understand ugliness? Returning to the photograph, might my response be more simply one of extreme repulsion? We are repulsed by many things that are ugly: rotten meat, carrion eaters and certain insects. Yet there appears to me to be a fundamental difference between ugliness and repulsion. I am repulsed by an excess, an intolerable too-muchness, that ugliness does not always have. I am repulsed by the excessively sweet, the excessively urbanized, the excessively beautiful as well. The grotesque face in the photograph is ugly and repulsive. Yet, not all ugly faces are repulsive. As I have argued, the ugly face can intrigue one by attracting one's eyes rather than forcing them away.

\section{To Encounter Ugliness is to be Brought Face to Face with the Other}

I must therefore believe that there might be more to this experience than merely being confronted with what I perceive as abject or repulsive in the other. But did the man's ugliness, and my 
experience of it, allow me to see him in a way that I would never be able to see another person? We might suspect that someone's extreme ugliness prevents my seeing another ${ }^{5}$. Is it not the case that I can empathize with the figure in the photograph who so horrifies me only when I am no longer looking at him? Or is it that I see something that the very act of looking denies when I cannot look?

I am reminded of Joseph Merrick, the famous $19^{\text {th }}$ Century "Elephant Man," who was toured, first, as a "carnival freak" and then, as a "medical oddity". The gazes that Joseph Merrick drew and held were not those of looking upon a fellow human being. Originally, they were the gazes of fairgoers staring at a "monster," a "freakish oddity," and then later of medical men examining an extraordinary specimen of "human deformity." The gazes that his ugliness held were not gazing upon his face, nor even upon his humanity but upon a "strange" and objective thing. ${ }^{6}$ Yet, "a face is a face by not being a rubbery substance to be grasped and palpated or a skull to be handled gingerly like a costly china bowl; it is a face by commanding the downcast eyes that touch it with respect” (Lingis, 1994, p. 44). Therefore, to have my eyes pushed downward by another's face may be to see that face in all of its mystery. The eyes that cannot look upon another's ugliness, the eyes that must turn away, are perhaps the only eyes that genuinely see.

Yet, the movement is paradoxical. While I cannot look upon the extremely ugly, do I not catch myself staring at the girl in class and the man on the train? How often do we admonish children not to stare at ugly people? Even adults may find that ugliness draws their eyes and have to force themselves to look away. We catch ourselves in order not to be caught by others. Might there be a similarity between involuntary and conscious looking away though? In both, we turn away in order not to see. John Berger (1977) remarks that, "we only see what we look at. To look is an act of choice. As a result of this act, what we see is brought within our reach..." (p. 8). To look upon an ugly face is then to bring another and his or her ugliness within our reach. To turn away is to deny it by fleeing. From what do we flee however? What does ugliness show us and offer us that we do not want to see or take hold of?

I return to the ugly face in the photograph. In the moment of ugliness, I do not recognize the other. I do not "perceive [him] to be the same as something or someone previously known or encountered," nor do I “accept the authority, validity, or legitimacy of” him or her (Oxford English Dictionary, 2010, definition of to recognize) as a human being like all other human beings. If, as Alphonso Lingis (1996) suggests, "in his or her face the other is other" (p. 67), perhaps when the hideous face appears before me suddenly, unexpected, and in all of its ugliness, I see that face as the absolute other, the complete unknown - as something that is ultimately the case for any other human being. It may even be that another's ugliness so overrides their recognizability that it strips the face of being a face at all. If beauty is only skin deep, but ugly is to the bone, ${ }^{7}$ as the old saying goes, perhaps we are able to see in another's ugliness - their raw humanity and their absolute otherness - the bare bones of who they are. Faced with this, my response can be to stare unwittingly or to turn away unable to bear its sight. In the former, I am held to it, almost against my will, while with the latter, I refuse and reject what I cannot bare to see. And yet, what causes such a duality of response? Alphonso Lingis (1996) suggests that encountering the face of the other "is to acknowledge a claim; it is answer to his or her appeal and respond to his or her order” (p. 72). Therefore, perhaps when we turn away from the ugly face of another, by choice or necessity, we flee the appeal, the claim of the other. 
We turn away from Joseph Merrick so we do not see a man treated like an animal and specimen or a man deprived of his basic humanity simply because of his ugly face.

\section{Ugliness as Moral Failure}

Citing traditional Christian ideas, Naomi Baker (2010) asks, "Does an ugly face reveal a corrupt soul?” Do we perceive another's ugliness as a moral failing, a critical flaw that is evidenced by his or her ugliness? We readily describe the "wicked" stepmothers of fairy tales, the mean bully of childhood, "haranguing" fishwives and "bloody warlords" as "ugly." In a Christian reference to the belief that the horrific nature of their actions have become etched upon their faces, we might even say they are ugly as sin. According to this tradition, the visage of an "ugly person" appears to physically manifest their corrupt soul. For some, it may be as if they bear the mark of the biblical character of Cain.

While imaginings, children's stories and popular media bear this perspective out, I would not declare the ugly man on the train or the ugly girl in my class or the photo of the deformed face as morally corrupt. For I must ask: Do I not hide behind fairy tales, stories, and my own imaginings to avoid a harsher truth? Might I myself might agree with Naomi Baker reference that an ugly face reveals a corrupt soul?” According to Herman Parret (2009), “the malaise that ugliness provokes is a pain that belongs to the moral rather than aesthetic order" (p. 6). My response to ugliness, accordingly, is not a response on the aesthetic level, but on a moral one. Therefore, when I see and acknowledge another's ugliness, do I not condemn my own character? Perhaps this is what underlies the hesitancy that I have - and that others may share - in declaring someone ugly. When I say, "You are ugly,” I experience my own moral failure.

So perhaps in fleeing the ugliness that confronts me, I also flee something more. Do I encounter the limits of ugliness or what I can and cannot stand to look at? Or is it, perhaps, that I encounter the limits of humanity, i.e. not another's but my own? I may encounter a limit to myself beyond which I do not want to and dare not be pushed. This is a limit within myself beyond which lies a terror that I flee.

\section{The Pain and Shame of Ugliness}

Ugliness, then, can be painful and difficult to encounter. Consider the following simple account:

My new teacher is... ugly. There is no other word for it. I look down and away but my eyes soon return.

Yes. She is shockingly ugly.

Even as I acknowledge it, I pause. 'Ugly' is not a word I have ever used to describe someone. I have an ugly dress and the painting hanging in the stairwell at the library is definitely ugly. But a person? Even when I have cared for severely disfigured people, I have never thought of them as "ugly." To consider another person ugly seems wrong. 
But I do about my new teacher.

And she is.

I wonder why she merits such a dark adjective. It seems base to think it. Mean. But I can't help it. Her large head is attached crookedly to her body. And while her cap, at first glance, looked askew on the tight curls of her hair, it is her head that is strangely angled. The features of her face, too, are not exactly where one expects them to be. They are just a little off: small, deep set eyes, a bulbous nose, and a long slit of a mouth that seems without lips.

I stop “assessing” her. It makes me feel bad for her. And about me.

As a student, I am struck by my teacher's ugliness and yet, more than that, I am struck by my own judgment and its finality. Alphonso Lingis suggests, "It is on the faces of others that we discover their values,” (1994, p. 66). Thus when I gaze upon my teacher's ugly face, I am forced to face, acknowledge, and to question my own assessments and labeling. The way I perceive my teacher's appearance does not just call itself to my awareness, it does not just call me into awareness, it does not just cause me to imagine her life, it shows me to myself. For in seeing another's ugliness, in my very noticing, I am confronted by something of myself that I did not notice before and it is something I do not like. Indeed, I am reluctant and ashamed to admit that I find someone ugly. I may censure myself in my response: I should know better; I shouldn't respond in this way; imagine if other people knew! If "disgust relies on moral obtuseness" (Nussbaum, 2010, p. xvii), I must ask about the degree to which Nussbaum's designation of moral obtuse also applies to me. What is wrong with me that I should see others so? To experience another as ugly can then be a shameful, ugly secret.

When I hide from or deny the experience of ugliness, what is the secret that I am hiding from? What precisely is It that I avoid by avoiding an acknowledgment of ugliness? In his book, Bad Mouth: Fugitive Papers on the Dark Side, Robert Adams (1977) notes how:

We reject the really ugly, or undergo sensations like horror and disgust that make us aware of ourselves. And perhaps this is why the ugly is commonly a violent shocksensation; memories of it may haunt a viewer in spite of himself, and then the terminology will be drawn from obsession and incubism, but some element of violation is I think inevitable. (p. 103)

The sometimes visceral distaste I sometimes feel in the face of ugliness may be more a distaste and rejection of my own response. For Martha Nussbaum (2010), contamination is central to the experience of disgust. "The disgusted person feels defiled by the object, thinking that it has somehow entered the self" (Nussbaum, 2010, p. 14). Ugliness may threaten to violate us by becoming part of us; and our turning away may be a resistance of that violation-- of the ugliness becoming part of us. In this, I may find the source of my denial, disavowal of ugliness and its very existence. For in bringing these words forth, "you are ugly," I give them life. ${ }^{8}$ The life I give these words, however, is my own. It is not the life of someone else. As I speak them in the 
world, they seem to refract back on me, reflecting much more on me than on any other. In recognizing ugliness, we are ashamed because we realize we, too, are ugly.

\section{Conclusion}

Ugliness can been called "the shadow form of the beautiful, its silent, invisible partner" (Gigante, 2000, p. 565). Perhaps the silence of ugliness, its apparent invisibility, is less its own than something that belongs to us; something deeply embedded in our refusal to acknowledge, much less speak of, ugliness when it is encountered. To see ugliness is to draw it upon ourselves. We may therefore attempt to keep it at a distance by denying its existence altogether (as in the commonly stated, "I have never seen an ugly person”) or by calling it "invisible," or something that, if it is present, simply cannot be seen and thus acknowledged.

Invariably in my searching, I am drawn back to where I began: with the girl in my class and my original question of what I experienced in the moment of my perception of her ugly face. Ages have passed since that first encounter, and their passage has been marked by innumerable encounters and conversations. That girl is now a good friend and I wonder at how I could ever have found her ugly. She is lively, lovely, and I must now even say "beautiful." And yet, her face is the same. There has been no great metamorphosis from awkward chick to beautiful swan. She looks no different. She only looks a bit older. Yet she is no longer ugly. It is as if her face has shed its ugliness to reveal another, more genuine visage to me. I cannot deny my perception of her original ugliness. If ugliness is a "shadow form” as Gigante (2000) suggests, I would argue that it is neither invisible nor silent. Rather, it is a shadow that can obscure our seeing. Its speaking can drown out all other sound. And yet ugliness is a voice and a sight that we should hesitate to deny, for in doing so, we are not denying an objective aspect of reality or an aesthetic opinion, but a part of ourselves.

\section{Acknowledgements}

This paper was originally written as part of a graduate level course the author audited during the 2010-2011 academic year. The author would like to thank Drs. Max van Manen and Catherine Adams, as well as her fellow classmates, for their generous support and constructive feedback given at all stages of this paper's development.

\section{Endnotes}

1 Sander Gilman (1995) extensively explores the long-standing association, and resulting implications, of beauty=health, ugliness=illness.

2 In 1992, Deborah Grady and Virginia Ernster argued that showing youth the effects that smoking cigarettes would have on their appearance, particularly upon their faces, would be a highly effective smoking prevention strategy.

${ }^{3}$ David Orr (1996) writes "Ugliness signifies a ...fundamental disharmony between people and between people and the land. Ugliness is, I think, the surest sign of disease” (p. 230). 
${ }^{4}$ For Mark Hutchinson (2002), "a face with disproportionate features may not be considered beautiful but is not ugly: a face lacking in features... is what is ugly. It threatens to stop being a face at all” (p. 11).

${ }^{5}$ Indeed, Coleridge adopted this view when he wrote "when [the soul] encounters the ugly it shrinks back and rejects it and turns away from it and is out of tune and alienated from it" (cited in Gigante, 2000, p. 579).

${ }^{6}$ While one could consider the manner in which the fairgoers and physicians viewed Joseph Merrick to be historically specific and a product of its time, particularly in terms of the scientific beliefs and practices of the day and the popularity of the "freak show," it is important to recognize that the objectifying gaze that their actions embody remains a present day concern in both medical science and popular culture. Moreover, it would be misleading to assume that the fairgoers and physicians only approached Merrick as an animal. Rather, the late $19^{\text {th }}$ and early $20^{\text {th }}$ century attitude towards physical anomalies did admit Merrick to be a human being, but one with a "spectacular body" to use Rosemarie Garland Thomson's (1996) phrase. The relationship the public and medical scientists had to Merrick and other "freaks" is a complex one that has taken other authors' volumes to explicate. Here, I only wish to draw upon the observation that in looking at - or rather, standing back and gazing directly upon - Merrick, the audience (whether fairgoer or physician) approaches him as an objective thing that can be directly observed, rather than as a fellow person who very human-ness will invariably forever remain a mystery.

7 "Beauty is only skin deep, but ugly is to the bone" is a saying that has multiple and contradictory interpretations. Some interpret it to mean that beauty is a superficial quality that can hide, but not cancel out, the ugliness of a person's personality. Others see it as implying that beauty is something we see, while ugliness is something we are. In this case, the former is seen as having little value, while the latter is conceived as a profound human flaw if it is allowed to develop. When the saying is applied with the latter meaning in mind, it is often used to censure an individual's 'ugly' actions. Others, still, read the phrase as implying that someone's beauty may be superficial and easily lost but if they are visibly ugly, their ugliness is deeply ingrained in who they are and it cannot be changed. The origin of the saying only further complicates the various interpretations. The saying seems to originate from the phrase "Beauty is but skin deep" first written by John Davies in 1616 about a woman who murdered her husband, and a variant later appeared in the rhyme "Beauty is but skin deep, ugly lies the bone;/ Beauty dies and fades away, but ugly holds its own." Here, the beauty of the body is acknowledged as temporary and fleeting in the face of death, which reduces all humans to ugly bones for eternity.

${ }^{8}$ Alphonso Lingis (1994) writes, "It is because we see that our flattering and slandering words color and stiffen the corporeal substance of the one to whom we address them, even while his or her mind rejects them, that we believe our blessings and curses alter the course of things, even though our professed mechanism has long since isolated nature in itself from the enchantment of our voice” (p. 5). 


\section{References}

Adams, R. (1977). Bad mouth: Fugitive papers on the dark side. Berkeley, CA: University of California Press.

Baker, N. (2010). Plain ugly: The unattractive body in early modern culture. Manchester: Manchester University Press.

Berger, J. (1977). Ways of seeing. New York, NY: Penguin Books.

Burke, E. (1958/ 2008). A philosophical enquiry into the sublime and beautiful. New York, NY: Routledge Classics.

De Saint Cheron, M. (2010). Conversations with Emmanuel Levinas, 1983-1994. Pittsburgh, PA: Duquesne University Press.

Eco, U. (2007). Introduction. In U. Eco (Ed.), On ugliness (pp. 8-21). New York, NY: Rizzoli.

Fink, B., Neave, N., Manning, J.T., \& Grammer, K. (2006). Facial symmetry and judgments of attractiveness, health and personality. Personality and Individual Differences, 41, 491-499.

Frith, K., Shaw, P., \& Cheng, H. (2005). A cross-cultural analysis of women's magazine advertising. Journal of Communication, 55(1), 56-70.

Garland Thomson, R. (1996). Freakery: Cultural spectacles of the extraordinary body. New York, NY: New York University Press.

Gillman, S. (1995). Picturing health and illness: Images of difference. London: Reaktion Books.

Gigante, D. (2000). Facing the ugly: The case of Frankenstein. ELH, 67(2), 565-587.

Grady, D., \& Ernster, V. (1992). Does cigarette smoking make you ugly and old? American Journal of Epidemiology, 135(8), 839-842.

Green, R.D., MacDorman, K.F., Ho, C.-C., \& Vasudevan, S. (2008). Sensitivity to the proportions of faces that vary in human likeness. Computers in Human Likeness, 24, 24562474.

Hall, S. The spectacle of the "other." In S. Hall (Ed.), Representation: Cultural representations and signifying practices (pp. 223-290). Thousand Oaks, CA: SAGE Publications.

Hutchinson, M. (2002). Nausea: Encounters with ugliness. Nottingham, UK: Djanogly Art Gallery.

Jones, B.C., Little, A.C., Penton-Voak, I.S., Tiddeman, B.P., \& Burt, Perrett, D.I. (2001). Facial symmetry and judgments of apparent health: Support for a "good genes" explanation of the 
attractiveness-symmetry relationship. Evolution and Human Behavior, 22, 417-429.

Kristeva, J. (1941). Powers of horror: An essay on abjection. New York, NY: Columbia University Press.

Lewis, C.S. (1956). Till we have faces: A myth retold. Grand Rapids, MI: William B. Eerdmans Publishing Company.

Lingis, A. (1994). The community of those who have nothing in common. Bloomington, IN: Indiana University Press.

Lingis, A. (1996). Sensation: Intelligibility in sensibility. Atlantic Highlands, NJ: Humanities Press International.

Lorrand, R. (1994). Beauty and its opposites. The Journal of Aesthetics and Art Criticism, 52(4), 399-406.

Nussbaum, M. (2010). From disgust to humanity: Sexual orientation and the law. Oxford, UK: Oxford University Press.

Online Etymological Dictionary. (2010). Retrieved from http://www.etymonline.com/

Orr, D. (1996). Ecological literacy. In M.A. Cahn \& R. O’Brien (Eds.), Thinking about the environment: Readings on politics, property and the physical world (pp. 227-234). Armonk, NY: M.E. Sharpe.

Oxford English Dictionary (4th ed). (2010). Oxford, UK: Oxford University Press.

Parret, H. (2009). The ugly as the beyond of the sublime. In C. Madelein, J. Pieters, \& B. Vandenabeele (Eds.), Histories of the sublime (pp. 59-68). Cambridge: Cambridge University Press. Available at http://www.hermanparret.be/bibliography.htm

Pereiro, X. (2006). Annotations on architecture, space and culture. In A. Baamonde et al (Eds.), Ugliness? destroying a country: The end of the humanized territory - a new kind of innercolonialism (pp. 43-44). Ourense: Difusora de Letras, Artes e Ideas.

Quinn, P.C., \& Slater, A. (2003). Face perceptions at birth and beyond. In O. Pascalis \& A. Slater (Eds.), The development of face processing in infancy and early childhood: Current perspectives (pp. 3-11). Hauppauge, NY: Nova Science Publishers.

Rozin, P., Haidt, J. \& Fincher, K. (2009). From oral to moral. Science, 27, 1179-1180.

Singh, D., \& Singh, D. (2011). Shape and significance of feminine beauty: An evolutionary perspective. Sex Roles, 64(9-10), 723-731. 